\title{
ANALISIS FAKTOR YANG BERHUBUNGAN DENGAN KEJADIAN HEPATITIS B PADA PENDONOR DI UNIT TRANSFUSI DARAH KOTA BENGKULU
}

\author{
Connya Talitha Rambe ${ }^{1}$, Besly Sinuhaji ${ }^{2}$, Dessy Triana $^{3 *}$, Marisadonna Asteria ${ }^{4}$, \\ Maria Eka Patri Yuliyanti ${ }^{5}$ \\ $1,2,3,4,5$ Universitas Bengkulu \\ e-mail: dessy.triana@unib.ac.id
}

\begin{abstract}
ABSTRAK
Angka kejadian Hepatitis B masih sangat tinggi di dunia dan Indonesia, perjalanan penyakit secara kronis menjadi kanker hati. Kejadian Hepatitis B memiliki banyak faktor risiko seperti faktor sosiodemografi, gaya hidup dan golongan darah. Tujuan penelitian adalah menganalisis pengaruh faktor sosiodemografi dan golongan darah terhadap kejadian hepatitis B. Jenis penelitian adalah penelitian retrosprektif dari tahun 2018-2020. Subjek penelitian sebanyak 100 orang. Teknik pengambilan data dengan teknik simple random sampling dari data rekam medis PMI Kota Bengkulu. Hasil penelitian menunjukkan jenis kelamin laki-laki sebanyak 84 orang (84\%) dan perempuan sebanyak 16 orang $(16 \%)$. Usia subjek penelitian paling banyak ada pada rentang 20-29 tahun (43\%). Pekerjaan yang terbanyak mengalami infeksi hepatitis B adalah wiraswasta (28\%). Golongan darah yang paling banyak mengalami infeksi Hepatitis B adalah golongan darah $\mathrm{A}^{+}(41 \%)$. Analisis multivariat dengan metode PCA menunjukkan secara statistik bahwa faktor eksternal (faktor pekerjaan) dan faktor internal (golongan darah, usia dan jenis kelamin) mempengaruhi kejadian Hepatitis B sebesar 36,3\% dan 27,5\%. Hasil regresi logistik menunjukkan terdapat pengaruh faktor eksternal dan internal terhadap kejadian Hepatitis B sebesar 26\%.
\end{abstract}

Kata Kunci: donor darah; golongan darah; Hepatitis B; Sosiodemograf

\begin{abstract}
The incidence of Hepatitis $B$ is still very high globally, and in Indonesia, the chronic manifestations become liver cancer. The incidence of Hepatitis $B$ has many risk factors such as sociodemographic factors, lifestyle, and blood type. The research aimed to analyze the influence of sociodemographic factors and blood type on the incidence of hepatitis B. This study was a retrospective study from 2018-2020. The research subjects were 100 people. The data collection technique used a simple random sampling technique from the medical record data of PMI Bengkulu City. The results showed 84 men (84\%) and 16 women (16\%). The age of most research subjects is in the range of 20-29 years (43\%). The occupation with the most hepatitis B infection is entrepreneurs (28\%). The blood group with the most hepatitis B infection was blood type A+ (41\%). Multivariate analysis using the PCA method showed statistically that external factors (occupational factors) and internal factors (blood type, age, and sex) affected the incidence of Hepatitis $B$ by $36.3 \%$ and $27.5 \%$, respectively. The logistic regression results showed an influence of external and internal factors on the incidence of Hepatitis B by $26 \%$.
\end{abstract}

Keywords: blood donation; blood type; Hepatitis B; Sociodemography 


\section{PENDAHULUAN}

Hepatitis $B$ adalah penyakit yang disebabkan oleh virus hepatitis B (VHB) yang biasanya tidak memiliki gejala kecuali telah berlangsung lama yang ditularkan melalui darah dan cairan tubuh seperti sperma, air susu ibu, dan air liur (Sharma et al., 2015). Virus hepatitis B akan menginfeksi hati yang dapat menyebabkan nekrosis hepatoselular dan inflamasi. Apabila dibiarkan dan bersifat kronik akan berkembang menjadi kanker hepatoselular. Menurut WHO penyakit ini menginfeksi dua miliar orang di seluruh dunia dan diperkirakan 350 juta diantaranya mengalami hepatitis Kronis (World Health Organization, 2015). Di Indonesia jumlah orang yang terinfeksi Hepatitis B yang didiagnosis oleh dokter mencapai angka 0,4\% di tahun 2018 dan jumlah orang yang terinfeksi hepatitis di provinsi Bengkulu mencapai angka $0,48 \%$ (Dinas Kesehatan Provinsi Bengkulu, 2019). Hepatitis dapat menular melalui darah sehingga dapat ditularkan kepada orang yang menerima donor darah apabila tidak dilakukan skrining dengan baik dengan angka kejadian 1:500.000 (Niederhauser, 2011)

Transfusi darah adalah tindakan medis yang dilakukan untuk penyelamatan hidup dan terapi, namun dalam penyediannya tidak selalu tercapai. Dalam penyediaan darah terdapat banyak regulasi yang harus dipenuhi baik dari pendonor maupun klinisi, hal-hal yang perlu diperhatikan melingkupi syarat pendonor, screening darah dan cara penyimpanan (Allard, 2013; World Health Organization, 2015). Saat melakukan transfusi darah dibutuhkan skrining ketat dari darah yang akan digunakan karena darah dapat menularkan jenis-jenis penyakit yang berbahaya dan bersifat kronik seperti Hepatitis B, Hepatitis C, Human Immunodeficiency Viral (HIV),dan sifilis kegiatan ini juga disebut predonation testing (Shittu, Olawumi and Adewuyi, 2014). Kejadian hepatitis B di Padang pada tahun 2012 dari hasil skrining darah oleh unit transfusi darah
(UTD) Palang Merah Indonesia (PMI) dengan prevalensi HBsAg reaktif 3,61\% (Oktavia, Yaswir and Harminarti, 2012), dan hasil skrining pada UTD PMI Provinsi Bali menunjukan 1,3\% reaktif HBsAg (Wulandari, 2016).

Faktor risiko dapat ditemukan baik pada orang yang sakit ataupun sehat. faktor risiko adalah keadaan atau karakteristik yang dapat meningkatkan keadaan sakit atau berkembang menjadi suatu penyakit.Faktor risiko mempunyai sifat antara lain dapat diubah dan tidak dapat diubah, yang bersifat dapat diubah adalah gaya hidup, kebiasaan di tempat kerja, dan lingkungan. Faktor risiko yang tidak dapat diubah adalah usia, jenis kelamin, etnis, genetik dan riwayat keluarga. (Dovjak, 2019). Hepatitis B memiliki faktor risiko yang beragam yaitu jenis kelamin laki-laki, usia, penggunaan jarum suntik, operasi besar pekerjaan dengan risiko tinggi, hubungan seksual sebelum menikah, kontak dengan keluarga yang memiiki riwayat hepatitis B dan transfusi darah (Sali et al., 2005). Faktor lain yang berpengaruh adalah riwayat hemodialisa, homoseksual dan heteroseksual, riwayat akupuntur, riwayat tindik dan tato (Gheorghe et al., 2013).

Dalam penelitian yang sudah dilakukan oleh Anaedobe rerata usia yang terinfeksi Hepatitis B adalah 32 tahun sebesar 55,6\% dan lebih banyak pada wanita yang bekerja sebesar $80 \%$ (Anaedobe et al., 2015). Menurut penelitian yang dilakukan oleh Drazilova jumlah laki laki yang terinkefsi hepatitis B lebih kecil dibandingkan pada wanita dan rata-rata berusia 34 tahun (Drazilova et al., 2018). peneltian yang di lakukan oleh Liu ditemukan golongan darah $\mathrm{O}$ lebih banyak mengalami hepatitis B (Liu et $a l ., 2018)$. Faktor lain yang berpengaruh ditemukan oleh Gheorghe adalah adanya riwayat transfusi darah (OR=1,37, CI: $1,37-1,80 ; P=0,022)$,dan orang dengan pasangan seksual lebih dari satu $(5,5$ vs. $4,2 \% ; P=0,024)$ (Gheorghe et al., 2013). 
Data mengenai penyakit infeksi menular akibat transfusi darah belum tersedia, sehingga tujuan penelitian untuk melakukan skrining dan analisis kejadian Hepatitis B berdasarkan sosiodemografi dan golongan darah.

\section{METODE PENELITIAN}

Penelitian ini telah mendapatkan persetujuan dari Komite Etik Penelitian Kesehatan Fakultas Kedokteran dan Ilmu Kesehatan Universitas Bengkulu nomor 145/UN30.14.9/LT/2021. Jenis penelitian pada penelitian ini adalah deskriptif dengan metode pengambilan sampel secara simple random sampling dari tahun 2018-2020. Penelitian dilakukan di Unit Transfusi Darah Palang Merah Indonesia Kota Bengkulu pada Bulan Juni-Juli 2021 dengan mengambil data rekam medis tahun 2018-2020. Populasi penelitian adalah Seluruh pendonor yang reaktif $\mathrm{HbsAg}$ ditahun 2018-2020. Pengelompokkan data menggunakan metode Principal Component Analysis (PCA) untuk menentukan faktor yang memiliki pengaruh terhadap kejadian hepatitis B. Kemudian dilakukan uji multivariat regresi logistik untuk melihat hubungan antar variabel. Perhitungan besar sampel untuk populasi terjangkau pada penelitian ini dapat digunakan rumus berikut, (Saryono, 2011).

$n=\frac{(\mathrm{Z} \alpha)^{2} \mathrm{PQ}}{\mathrm{d}^{2}}$

Keterangan:

$\mathrm{Z} \not \alpha=$ kesalahan tipe $1(\mathrm{Z} \underline{\alpha}=1,96)$

$\mathrm{P}=$ Proporsi

$\mathrm{Q}=1-\mathrm{P}$

$\mathrm{D}=$ presisi

$n={\frac{(1,96)^{2} \cdot 0,5 \cdot 0,5}{(0,01)^{2}}}_{n=97}$

Berdasarkan perhitungan sampel tersebut, didapatlan jumlah sampel penelitian minimal 97sampel.

\section{HASIL DAN PEMBAHASAN}

Tabel 1. Distribusi Frekuensi Karakteristik subjek penelitian

\begin{tabular}{ccc}
\hline & Karakteristik & $\begin{array}{c}\text { Frekuensi } \\
(\mathbf{\%})\end{array}$ \\
\hline Jenis & Laki-laki & $84(84 \%)$ \\
kelamin & Perempuan & $16(16 \%$ \\
\hline Usia & $<20$ tahun & $1(1 \%)$ \\
& $20-29$ tahun & $43(43 \%)$ \\
& $30-39$ tahun & $27(27 \%)$ \\
& 40-49 tahun & $23(23 \%)$ \\
& 50-59 tahun & $6(6 \%)$ \\
& . 60 tahun & 0 \\
\hline Pekerjaan & TNI/Polri & $8(8 \%)$ \\
& Pegawai negeri/ & $18(18 \%)$ \\
& swasta & $12(12 \%)$ \\
& Petani /buruh & $28(28 \%)$ \\
& Wiraswasta & $13(13 \%)$ \\
& mahasiswa/pelajar & $2(2 \%)$ \\
& Pedagang & $19(19 \%)$ \\
\hline \multirow{3}{*}{ Golongan } & lain-lain & $41(41 \%)$ \\
Darah & A & $21(21 \%)$ \\
& B & $15(15 \%)$ \\
& AB & $23(23 \%)$ \\
\hline
\end{tabular}

Sumber: Data primer penelitian (2021).

Tabel 1 menunjukkan karakteristik jenis kelamin laki-laki sebesar $84 \%$ dan perempuan sebesar $16 \%$. Usia subjek penelitian paling banyak ada pada rentang 20-29 tahun yaitu sebanyak 43 orang $(43 \%)$. Pekerjaan yang paling banyak mengalami infeksi hepatitis B yaitu wiraswasta sebanyak 28 orang (28\%). Golongan darah yang paling banyak mengalami infeksi Hepatitis B adalah golongan darah $\mathrm{A}^{+}$sebanyak 41 orang $(41 \%)$.

Hasil analisis data diperoleh jenis kelamin yang paling banyak terinfeksi Hepatitis B adalah laki-laki. Hal ini sesuai dengan data Kementerian Kesehatan RI tahun 2013 melaporkan jumlah laki-laki lebih banyak menderita hepatitis B (Litbangkes Kementerian Kesehatan, 2013). Penelitian sebelumnya di unit transfusi darah kota Bali menunjukan laki-laki lebih banyak terdeteksi hepatitis $\mathrm{B}$, kemungkinan 
terjadi karena donor laki-laki jauh lebih banyak dibandingkan perempuan dan beberapa kondisi yang menyulitkan perempuan untuk melakukan donor sepert haid, hamil, dan menyusui. Kadar hemoglobin yang rendah juga menjadi penyebab kegagalan menjadi pendonor bagi perempuan (Wulandari, 2016). Menurut penelitian yang dilakukan oleh milkias laki laki yang terinfeksi Hepatitis B lebih banyak dibandingkan wanita karena hal ini dapat terjadi karena HBsAg pada perempuan lebih cepat turun dibandingkan pada laki-laki (Abebe, Alemnew and Biset, 2020).

Rentang usia yang paling banyak mendonorkan darahnya adalah 25-44 tahun karena rentang usia ini masih produktif dan memiliki kondisi tubuh yang masih normal sehingga memenuhi persyaratan donor, penelitian serupa yang dilakukan oleh Wulandari tahun 2016, rentang usia pendonor dengan Hepatitis B pada usia 16-30 tahun dan rentang usia ini lebih rentan terhadap faktor risiko (Oktavia, Yaswir and Harminarti, 2012; Wulandari and Mulyantari, 2016). Menurut penelitian yang dilakukan oleh Aneodobe yang dilakukan pada ibu hamil angka hepatitis lebih tinggi pada ibu yang berusia 29-35 hal ini dikaitkan dengan usia pertama kali melakukan kegiatan seksual (Anaedobe et al., 2015).

Golongan darah yang paling banyak terinfeksi adalah golongan darah $\mathrm{A}$. Sejalan dengan penelitian yang dilakukan oleh Genc tahun 2017 yang menemukan golongan darah A lebih banyak terinfeksi dibandingkan golongan darah lain (Genc, 2017). Penelitian lain yang dilakukan oleh Batool tahun 2017 yang menemukan golongan darah A lebih memiliki risiko untuk mengalami hepatitis B dan HIV (Batool, Durrani and Tariq, 2017). Hasil penelitian oleh Liu di china golongan darah yang paling banyak mengalami hepatitis B adalah golongan darah $\mathrm{O}$ (Liu et al., 2018).

Wiraswasta adalah pekerjaan dengan angka tertinggi infeksi Hepatitis B pada penelitian ini. Penelitian yang dilakukan oleh Corderio menunjukan angka tertinggi terinfeksi hepatitis B adalah petugas medis (Cordeiro, 2019). Penelitian yang dilakukan Farshadpour, pekerjaan yang paling banyak menderita Hepatitis B adalah wiraswasta, tetapi yang pekerjaan yang berpengaruh dengan kejadian hepatitis B adalah wajib militer dan pensiunan (Farshadpour et al., 2016). Pada penelitian yang dilakukan oleh Abebe pekerjaan yang paling banyak mengalami Hepatitis B adalah pelajar (Abebe, 2020).

Hasil Uji Principal Component Analysis didapatkan nilai KMO MSA = 0,530 dan nilai siginifikansi Bartlett sebesar 0,004. Berdasarkan hasil tersebut, maka syarat pertama uji PCA terpenuhi dan proses analisa data dapat dilanjutkan. Hasil Luaran Total Varians Explained dua komponen yang memiliki nilai total Initial eigenvalues dan/atau nilai total pada extraction Sum of Square Loadings $>1, \quad$ sehingga dapat diinterpetasikan bahwa dalam penelitian ini terdapat 2 faktor dari 4 variabel yang dianalisis.

Tabel 2. Luaran Komponen Matriks

\begin{tabular}{lcr}
\hline & \multicolumn{2}{c}{ Rotated Component } \\
& \multicolumn{2}{c}{ Matrix } \\
\cline { 2 - 3 } & 1 & 2 \\
\hline Usia &,- 766 &,- 240 \\
\hline $\begin{array}{l}\text { Golongan } \\
\text { darah }\end{array}$ &,- 160 &, 821 \\
\hline Pekerjaan &, 821 &,- 128 \\
\hline Jenis kelamin &, 301 &, 657 \\
\hline
\end{tabular}

Sumber: Data primer tahun 2021.

Pada tabel 2 terlihat hasil nilai korelasi variabel usia dengan faktor 2 lebih kecil daripada nilai korelasi antara usia dengan faktor $1(-0,240>-0,766)$. Hasil interpretasi bahwa usia termasuk dalam faktor 2. Variabel golongan darah memiliki korelasi yang lebih tinggi terhadap faktor 2 dibandingkan korelasi terhadap faktor $1(0,821>-0,160)$. Hasil interpretasi bahwa variabel golongan darah termasuk ke dalam faktor 2 .

Korelasi antara variabel pekerjaan dengan faktor 1 diketahui memiliki nilai yang lebih tinggi daripada nilai korelasi 
variabel pekerjaan terhadap faktor 2 $(0,821>-0,128)$, maka dapat diinterpetasikan bahwa variabel pekerjaan termasuk dalam faktor 1 . Jenis kelamin memiliki nilai korelasi lebih tinggi terhadap faktor 2 daripada terhadap faktor $1(0,657>0,301)$. Hal ini memberikan interpretasi bahwa variabel jenis kelamin termasuk ke dalam faktor 2 .

Hasil metode PCA didapatkan 2 faktor yang mempengaruhi kejadian Hepatitis B pada pendonor di UTD PMI Kota Bengkulu. Faktor pertama yaitu usia, jenis kelamin dan golongan darah yang kemudian disebut faktor internal. Faktor kedua yaitu pekerjaan yang kemudian disebut faktor eksternal, kedua faktor ini berpengaruh terhadap kejadian hepatitis B dengan cummulative variance percent sebesar $68,896 \%$. Sehingga 4 variabel tersebut berpengaruh terhadap kejadian Hepatitis $B$ dengan pembagian menjadi faktor internal dan faktor eksternal. Hasil uji multivariat regresi logistik menunjukkan terdapat pengaruh faktor eksternal dan internal terhadap kejadian Hepatitis B sebesar $26 \%$.

Berdasarkan jenis kelamin, kejadian Hepatitis B lebih banyak terjadi pada laki-laki dibandingkan perempuan, salah satu faktornya karena perbedaan hormon laki-laki dan perempuan. Dijelaskan pada penelitan sebelumnya mengenai kadar testosteron yang tinggi memiliki hubungan dengan kejadian risiko kanker hati yang lebih tinggi, didukung dengan adanya perbedaan hormon laki-laki dan perempuan dalam melepaskan sitokin inflamasi, ditemukan hasil bahwa perempuan dengan hepatitis carrier memiliki viral load yang lebih sedkit dibandingkan dengan laki-laki (Ruggieri, Gagliardi and Anticoli, 2018). Laki-laki juga lebih berisiko mengalami hepatitis karena aktivitas yang dilakukan seperti bekerja diluar rumah, aktivitas potong rambut dan kegiatan donor darah (Khan et al., 2011). Dalam penelitian mengenai penyakit menular yang di diderita sebelum transfusi darah, persentase laki-laki memiliki angka lebih tinggi dibandingkan perempuan karena perempuan lebih sedikit terlibat dalam interaksi sosial yang memiliki risiko seperti hubungan seksual berganti pasangan, penggunaan obat intravena, serta adanya perbedaan ras dan suku yang mengakibatkan perbedaan gaya hidup (Farshadpour et al., 2016)

Hepatitis B lebih banyak menginfeksi usia remaja hingga dewasa muda infeksi lebih tinggi, karena pada rentang usia ini lebih rentan terhadap faktor risiko Hepatitis B seperti penggunaan jarum suntik yang terkontaminasi dan hubungan seksual dengan orang yang terinfeksi. Terdapat penelitian yang menjelaskan kejadian lebih jarang pada usia lanjut diperkirakan bahwa virusnya telah hilang dari tubuh setelah mengalami hepatitis akut dan sehat (Kolou et al., 2017). Menurut penelitian yang dilakukan oleh Keleta, bahwa usia mempengaruhi kejadian hepatitis B dengan angka kejadian lebih banyak pada usia 19-35 tahun dan risikonya meningkat dengan bertambahnya umur (Keleta et al., 2019). Sementara itu, penelitian yang dilakukan oleh Farshadpour ditemukan usia juga berpengaruh terhadap kejadian Hepatitis B dengan usia dewasa lebih banyak terinfeksi Hepatitis B, hal ini dapat disebabkan semakin meningkatnya paparan terhadap virus karena perilaku yang dapat meningkatkan risiko terpapar virus hepatitis B seperti kebiasaan melakukan hubungan seksual bergantiganti pasangan (Farshadpour et al., 2016).

Berdasarkan peneletian yang dilakukan oleh Jing, terdapat hubungan golongan darah yang lebih tahan terhadap infeksi hepatitis B, kemungkinan besar terkait dengan respon imun yang berubah dan respon inflamasi sistemik yang terkait dengan fenotipe golongan darah yang berbeda. Sebuah penelitian sebelumnya telah melaporkan bahwa munculnya alkaline phosphatase usus dalam plasma dikaitkan dengan golongan darah $\mathrm{ABO}$ dan status sekretor, disebabkan oleh variasi yang ditentukan secara genetik dalam proporsi isoenzim diantara golongan darah yang berbeda (Jing et 
al., 2020). Penelitian oleh Genc, menemukan golongan darah tidak berhubungan dengan kejadian Hepatitis B namun hal ini masih belum ditemukan mekanismenya (Genc, 2017). Menurut penelitian yang dilakukan oleh Liu terdapat hubungan antara golongan darah dan hepatitis B dengan golongan darah $\mathrm{O}$ yang paling berisiko terkena hepatitis B, ditemukan dari beberapa penelitian sebelumnya terdapat hubungan dengan membran sel darah merah dan virus karena ada kesamaan antigenik, kemampuan perlekatan dengan reseptor spesifik atau dari respon imun (Liu et al., 2018).

Jenis pekerjaan juga mempengaruhi kejadian hepatitis B. Pada penelitian ini pekerjaan wiraswasta yang memiliki jumlah kejadian Hepatitis B paling tinggi karena sebanding dengan sampel penelitian yang sebagian besar (28\%) bekerja sebagai wiraswasta.

Pada penelitian yang lain menyebutkan pekerjaan dengan risiko paling tinggi terkena hepatitis B adalah tenaga kesehatan karena keberadaan dari tenaga kesehatan yang terus terpapar dengan pasien yang terinfeksi hepatitis B terutama yang bekerja didalam seperti perawat dan laboran (Ziraba et al., 2010). Dalam penelitian lainnya pekerjaan seperti polisi, dan pelayan publik lainnya lebih rendah untuk mengalami kejadian hepatitis sehingga tidak ditemukan adanya hubungan signifikan antara pelayan publik dengan kejaadian hepatitis B (Averhoff et al., 2002). Dalam penelitian yang dilakukan oleh Farshadpour menemukan kejadian Hepatitis B berhubungan dengan jenis pekerjaan, pekerjaan yang berpengaruh adalah wajib militer dan pensiunan namun alasannya masih harus diteliti lebih lanjut (Farshadpour et al., 2016).

\section{KESIMPULAN}

1. Jenis kelamin laki-laki yang paling banyak terinfeksi Hepatitis B, usia subjek penelitian paling banyak ada pada rentang 20-29 tahun, pekerjaan terbanyak adalah wiraswasta, dan golongan darah paling banyak adalah golongan darah A.

2. Faktor sosiodemografik dan golongan darah memiliki hubungan secara statistik terhadap kejadian hepatitis B.

3. Faktor yang mempengaruhi kejadian Hepatitis B dibagi menjadi 2 faktor, yaitu faktor eksternal (pekerjaan) sebesar 36,3\% dan faktor internal (usia, jenis kelamin dan golongan darah) sebesar 27,5\%

\section{SARAN}

1. Perlu dilakukan penelitian lebih lanjut untuk mengetahui faktorfaktor lain yang mempengaruhi kejadian hepatitis B di lokasi berbeda.

2. Edukasi berkelanjutan sangat diperlukan untuk memutus rantai penularan Hepatitis B yang disebabkan oleh faktor eksternal.

\section{REFERENSI}

Abebe, M., Alemnew, B. and Biset, S. (2020) 'Prevalence of hepatitis b virus and hepatitis $\mathrm{c}$ virus among blood donors in nekemte blood bank, Western Oromia, Ethiopia: Retrospective 5 years study', Journal of Blood Medicine, 11, pp. 543-550. doi: 10.2147/JBM.S282099.

Allard, S. (2013) 'Blood transfusion', Medicine, 41, pp. 242-247. doi: 10.1016/j.mpmed.2013.01.010.

Anaedobe, C. G., Fowotade, A., Omoruyi, C. and Bakare, R. (2015) 'Prevalence, sociodemographic features and risk factors of Hepatitis B virus infection among pregnant women in Southwestern Nigeria', Pan African Medical Journal, 20. doi: 10.11604/pamj.2015.20.406.6206.

Averhoff, F. M., Moyer, L. A., Woodruff, B. A., Deladisma, A. M., Nunnery, J., Alter, M. J. and Margolis, H. S. (2002) 'Occupational Exposures and 
Risk of Hepatitis B Virus Infection Among Public Safety Workers', Journal of Occupational and Environmental Medicine, 44(6), pp. 591-596. doi: $\quad 10.1097 / 00043764$ 200206000-00024.

Batool, Z., Durrani, S. H. and Tariq, S. (2017) 'Association Of Abo And $\mathrm{Rh}$ Blood Group Types To Hepatitis B, Hepatitis C, Hiv And Syphilis Infection, A Five Year' Experience In Healthy Blood Donors In A Tertiary Care Hospital', Journal of Ayub Medical College, Abbottabad: JAMC, 29(1), pp. 90-92.

Cordeiro, T. M. S. C., Ferreira Filho, R. $\mathrm{P}$. and D'Oliveira Júnior, A. (2019) 'Factors associated with occupational and nonoccupational viral hepatitis infections in Brazil between 2007-2014', Annals of Hepatology, 18(5), pp. 751-756. doi: 10.1016/j.aohep.2019.03.009.

Dinas Kesehatan Provinsi Bengkulu (2019) Profil Kesehatan Provinsi Bengkulu Tahun 2018. 210-221 p.

Dovjak, M. and Kukec, A. (2019) Creating Healthy and Sustainable Buildings, Creating Healthy and Sustainable Buildings. Cham: Springer International Publishing. doi: 10.1007/978-3-030-19412-3.

Drazilova, S., Janicko, M., Kristian, P., Schreter, I., Halanova, M., Urbancikova, I., MadarasovaGeckova, A., Marekova, M., Pella, D. and Jarcuska, P. (2018) 'Prevalence and Risk Factors for Hepatitis B Virus Infection in Roma and Non-Roma People in Slovakia', International Journal of Environmental Research and Public Health, 15(5), p. 1047. doi: 10.3390/ijerph15051047.

Farshadpour, F., Taherkhani, R., Tajbakhsh, S., Tangestani, M. G., Hajiani, G., Sharifi, N.,
Taherkhani, S. and Nejadbolkheyr, A. (2016) 'Prevalence and trends of transfusion-Transmissible viral infections among blood donors in south of Iran: An Eleven-Year retrospective study', PLOS ONE, 11(6), pp. 1-18. doi: 10.1371/journal.pone.0157615.

Genc, O. (2017) 'Hepatitis B virus infection and $\mathrm{ABO} / \mathrm{Rh}$ blood groups', International Journal of Research in Medical Sciences, 5(9), p. 3782. doi: 10.18203/23206012.ijrms20173949.

Gheorghe, L., Csiki, I. E., Iacob, S. and Gheorghe, C. (2013) 'The prevalence and risk factors of hepatitis B virus infection in an adult population in Romania', European Journal of Gastroenterology \& Hepatology, 25(1), pp. 56-64. doi: 10.1097/MEG.0b013e328358b0b b.

Jing, W., Zhao, S., Liu, J. and Liu, M. (2020) 'ABO blood groups and hepatitis B virus infection: a systematic review and metaanalysis', BMJ Open, 10(1), pp. 1-9. doi: 10.1136/bmjopen-2019034114 .

Keleta, Y. T., Achila, O. O., Haile, A. W., Gebrecherkos, B. H., Tesfaldet, D. T., Teklu, K. S., Mohammed, M. A. and Ghedel, S. T. (2019) 'Seroprevalence of transfusion transmitted infections among blood donors in Gash Barka Zonal Blood Transfusion Center, Barentu, Eritrea, 2014 through 2017', BMC Hematology, 19(1), pp. 1-9. doi: 10.1186/s12878-019-0136-5.

Khan, F., Shams, S., Qureshi, I. D., Israr, M., Khan, H., Sarwar, M. T. and Ilyas, M. (2011) 'Hepatitis B virus infection among different sex and age groups in Pakistani Punjab', Virology Journal, 8, pp. 1-5. doi: 10.1186/1743-422X-8- 
225.

Kolou, M., Katawa, G., Salou, M., Gozo-Akakpo, K. S., Dossim, S., Kwarteng, A. and Prince-David, M. (2017) 'High Prevalence of Hepatitis B Virus Infection in the Age Range of 20-39 Years Old Individuals in Lome', The Open Virology Journal, 11(1), pp. 1-7. doi:

10.2174/1874357901710011001.

Litbangkes Kementerian Kesehatan (2013) Riset Kesehatan Dasar 2013.

Liu, J., Zhang, S., Liu, M., Wang, Q., Shen, H. and Zhang, Y. (2018) 'Distribution of $\mathrm{ABO} / \mathrm{Rh}$ blood groups and their association with hepatitis B virus infection in 3.8 million Chinese adults: A population-based cross-sectional study', Journal of Viral Hepatitis, 25(4), pp. 401-411. doi: 10.1111/jvh.12829.

Niederhauser, C. (2011) 'Reducing the risk of hepatitis $\mathrm{B}$ virus transfusion-transmitted infection', Journal of Blood Medicine, p. 91. doi: 10.2147/JBM.S12899.

Oktavia, D., Yaswir, R. and Harminarti, N. (2012) 'Frekuensi Hepatitis B dan Hepatitis C Positif pada Darah Donor di Unit Transfusi Darah Cabang Padang pada Tahun 2012', Jurnal Kesehatan Andalas, 6(1), pp. 147-151.

Ruggieri, A., Gagliardi, M. C. and Anticoli, S. (2018) 'SexDependent Outcome of Hepatitis $B$ and $C$ Viruses Infections: Synergy of Sex Hormones and Immune Responses?', Frontiers in Immunology, 9. doi: 10.3389/fimmu.2018.02302.

Sali, S., Bashtar, R., Alavian, S. M., East, M. and Disease, L. (2005) 'Risk Factors in Chronic Hepatitis B Infection: A Case-control Study', Hepatitis Monthly, 5(4)(June 2014), pp. 109-1115.
Sharma, S., Carballo, M., Feld, J. J. and Janssen, H. L. A. (2015) 'Public Health Immigration and viral hepatitis', 63, pp. 515-522.

Shittu, A. O., Olawumi, H. O. and Adewuyi, J. O. (2014) 'PreDonation Screening of Blood for Transfusion Transmissible Infections: The Gains and The Pains - Expe-Rience At A Resource Limited Blood Bank', Ghana Medical journal, 48, pp. 158-162. doi: 10.4314/gmj.v48i3.8.

World Health Organization (2015) 'Guideline For The Prevention, Care And Treatment Of Persons With Chronic Hepatitis B Infection', Geneva. p. 124.

Wulandari, P. and Mulyantari, N. (2016) 'Gambaran Hasil Skrining Hepatitis B Dan Hepatitis C Pada Darah Donor Di Unit Donor Darah Pmi Provinsi Bali', EJurnal Medika Udayana, 5(7), pp. 7-10.

Ziraba, A. K., Bwogi, J., Namale, A., Wainaina, C. W. and MayanjaKizza, H. (2010) 'Sero-prevalence and risk factors for hepatitis B virus infection among health care workers in a tertiary hospital in Uganda', BMC Infectious Diseases, 10(May 2014). doi: 10.1186/1471-2334-10-191. 